Jaroslav Dad'o', Janka Taborecka - Petrovicova', ${ }^{1}$ Tamara Rajic ${ }^{2^{*}}$ ${ }^{1}$ Faculty of Economics, Matej Bel University in Banska Bystrica, Slovakia ${ }^{2}$ Economics Institute a.d., Belgrade, Serbia

\title{
Towards an Integrative Framework of Relationship Quality in a Retail Setting: Evidence from an Emerging Economy
}

DOI: 10.7595/management.fon.2021.0020

\begin{abstract}
:
Research question: This study aims to propose and empirically examine a relationship quality model in a grocery retail setting in Serbia. Motivation: Whereas relationship quality has been extensively studied in B2B settings and in developed economies, far less research attention has been devoted to the formation and effects of relationship quality in B2C exchange relations in developing economies. This especially holds true for Eastern Eupean emerging economies and the present research aims to fill this gap. Idea: Building upon previous research in service settings, this study proposes customer orientation as an antecedent to relationship quality, comprising relationship satisfaction, customer trust and commitment to a retailer, and attitudinal and behavioural loyalty as consequences of relationship quality. Data: The study has been performed on a convenience sample of 453 grocery retail customers in Serbia, by means of structured questionnaire. Tools: Upon supporting constructs' validity, structural equation modelling (SEM) has been applied to examine the proposed relationships. Findings: The results of the study indicate significant direct impact of employees customer orientation on trust and relationship satisfaction. Commitment to a retailer and relationship satisfaction emerged as direct antecedents to attitudinal and behavioural loyalty, whereas trust emerged as an indirect determinant of loyalty constructs. In terms of total effect, relationship satisfaction emerged as the most influential determinant of both facets of customer loyalty. Contribution: The findings of the study which indicate significant indirect contribution of front-line employees' customer orientation to attitudinal and behavioural loyalty of customers provide valuable insights for HR management of retail enterprises. In addition, by addressing relationship quality construct and its antecedents and effects in a B2C setting in thus far largely under-studied context, such as an emerging European economy, this study's findings add to the growing body of knowledge on Relationship Marketing.
\end{abstract}

Keywords: customer orientation, relationship quality, trust, relationship satisfaction, customer commitment, attitudinal loyalty, behavioural loyalty, grocery retailing

JEL Classification: M31, C30, D12

\section{Introduction}

Relationship quality has received considerable attention among academics and practitioners over previous three decades. High quality relationships with customers have been shown to lead to customer retention, cross-selling opportunities, customer referrals, lower exchange costs, higher market share and better business performance (Kim \& Cha, 2002; Kim et al., 2006; Qin et al., 2009; Lo et al., 2017; Santouridis \& Veraki, 2017; Bakator et al., 2019; Ledikwe et al., 2019; Rajic et al., 2019; Xu et al., 2020). Relationship quality is also valued as a source of sustainable competitive advantage, as intangible aspects of high quality relationships that a company may establish with customers cannot be easily duplicated by competitors (Athanasopoulou, 2009; Qin et al., 2009; Bowden-Everson et al., 2013; Kuhn \& Mostert, 2018; Prayag et al., 2019). Relationship quality is particularly relevant to service businesses, and especially in high-contact service settings, 
due to inherently intangible nature of services which causes customers' uncertainty prior to a service delivery (Palmatier et al., 2006; Delacroix \& Guillard, 2016).

Whereas the construct of relationship quality has been extensively studied from the perspective of B2B relationships, far less research attention has been devoted to relationship quality in $\mathrm{B} 2 \mathrm{C}$ exchange contexts (Olavarrýa-Jaraba et al., 2018), and according to Athanasopoulou (2009) relationships in B2B settings differ from relationships in retail contexts. Moreover, previous studies have mainly been conducted in the U.S., Western Europe and Asia, whereas little is known of the formation and consequences of quality relationships in $\mathrm{B} 2 \mathrm{C}$ exchange relations in emerging economies. This especially refers to emerging European economies, which have remained mostly under-studied, in comparison with Asian developing economies. In addition, a number of previous studies modelled relationship quality as a global/composite construct (e.g. Kim \& Cha, 2002; Kim et al., 2006; Cheng et al., 2008; Castellanos-Verdugo et al., 2009; Rajaobelina \& Bergeron, 2009). Contrary to previous research, this study addresses the construct at the level of its dimensions, following Balaji's (2015) and Izogo's (2016) assertions that customers are capable of making distinctions between different relationship quality dimensions and that a disaggregate model of relationship quality provides a better explanation of the formation of customer loyalty intentions.

Recent studies in the context of service businesses have pointed to the company's customer orientation as an important precondition for the establishment of quality relationships with customers and documented significant impact of relationship quality on customers' willingness to repurchase, continue relationship with a provider and spread positive word-of-mouth (Castellanos-Verdugo et al., 2009; Lo et al., 2017; Prayag et al., 2019).

In order to address the aforementioned gaps in the literature, this study builds upon previous research in service businesses and aims to examine the impact of retailers' customer orientation on relationship quality and the contribution of its constituents, trust, relationship satisfaction and commitment to a retailer, on attitudinal and behavioural loyalty of customers in the context of an emerging Eastern European economy.

Serbian grocery retailing provided the context for this study. From the beginning of the $21^{\text {st }}$ century Serbia has opened its market to foreign entrants, whereas retail trade has experienced the highest deregulation in Serbian business economy. Consequently, grocery retailing in Serbia has been increasingly exposed to competitive pressures and subject to significant changes. According to a recent research of the Serbian Commission for the Protection of Competition into the sales in non-specialized stores with food, beverages and tobacco predominating assortment, traditional grocery stores (with sales area less than $200 \mathrm{~m}^{2}$ ) still dominate the market with $80 \%$ in total number of retail stores, however, they have been gradually giving way to modern retail formats, instituted mainly by market entrants (Commission for protection of competition of the Republic of Serbia, Sectoral analysis, 2018). This trend has already been recorded in emerging economies opening their market to foreign companies (Paul et al., 2016). Whereas modern retail formats account for only $1 \%$ share in total number of stores, they generate $18 \%$ of total revenues (Commission for Protection of Competition of the Republic of Serbia, Sectoral analysis, 2018). According to the Commission's report, market entrants have not identified barriers to entry and further modernization and structural changes in non-specialized retailing of food, beverages and tobacco products are expected.

The remainder of the paper is structured as follows: Theoretical framework of the study is discussed in the next section and research hypotheses are proposed. This is followed by a brief overview of methodology and the discussion of research findings. Theoretical and managerial implications are outlined subsequently and limitations of the study and directions for future research are highlighted.

\section{Conceptual Framework and Research Hypotheses}

\subsection{Relationship quality}

In a retail setting relationship quality has been explained as a customer's reliance on salesperson's integrity and his confidence in the future performance of a salesperson, which is based on previously satisfying interactions with the salesperson (Qin et al., 2009). Relationship satisfaction, trust in a provider and commitment to the relationship with a provider have been the most commonly suggested dimensions of relationship quality in B2C markets (Hennig-Thurau et al., 2002; Athanasopoulou, 2009; Lo et al., 2017; Olavarrýa-Jaraba et al., 2018; Ledikwe et al., 2019). One should also be aware that although some consumers may be seemingly satisfied with a product or a service delivery, not all of them will be equally willing to engage into commercial relationships, as for some of them relational tactics may be perceived as implying the loss of privacy 
and intimidating (Noble \& Phillips, 2004; Delacroix \& Guillard, 2016). However, relationship hindrances are beyond the scope of the present study.

Moorman, Zaltman and Deshpande (1992) defined trust as 'the willingness to rely on an exchange partner in whom one has confidence' (p. 315). According to Rajaobelina and Bergeron (2009), trust comprises two elements, customers' belief in an exchange partners' expertise and a belief that the other party will behave in a responsive and mutually beneficial manner when new circumstances emerge. Trust in an exchange partner reduces customer's risk perceptions and instills confidence into customers of the exchange partner's integrity and reliability (Kim et al., 2006; Wu et al., 2019). Previous research has highlighted significant contribution of trust in an exchange partner in the formation of relationship satisfaction (Balaji, 2015).

De Wulf et al. (2001) define relationship satisfaction as 'an overall appraisal of his or her relationship with a retailer' (p.36). It is an affective state which is based on consumer's assessment of interactions with the retailer over the course of a relationship. As such it differs from a satisfying experience which results from a particular transaction with a retailer.

Moorman et al. (1992) explain customer commitment as an 'enduring desire to maintain a valued relationship' (p. 316). Customer's willingness to maintain a long-term relationship with a company is based on customer's belief that continuing the relationship will bring higher net benefits than terminating it (Hennig-Thurau et al., 2002). Commitment is regarded as a key driver of customer loyalty in service settings (Fullerton, 2005; Balaji, 2015). It stems from the provision of services which exceeds customer expectations (Bowden-Everson et al., 2013). Whereas some previous studies addressed commitment as a multidimensional construct, consisting of continuance and affective commitment (Fullerton, 2005; Lee et al., 2007), or calculative, affective and normative commitment (Bowden-Everson et al., 2013), the authors of this study acknowledge prior findings and adhere to Olavarrýa-Jaraba et al.'s (2018) stance that in buyer-seller relationships customers feel no obligation to stay in a relationship, but their commitment stems from affective attachment to the provider. In addition, Lee et al. (2007) claim that continuance commitment is a feature of B2B relationships, due to common existence of high switching costs, scarcity of alternatives and contractual nature of a relationship between exchange partners, which is not the case in highly competitive context of grocery retailing, where customer commitment is based on an emotional attachment towards a retailer. This study therefore builds upon a conceptual framework including an affective component of commitment.

Recent empirical research has indicated a significant impact of customer trust on satisfaction with a service provider (Wu et al., 2019). The antecedents role of relationship satisfaction to relationship commitment has been also empirically supported (Balaji, 2015). Kim et al.'s (2006) research provided evidence of a significant positive influence of both trust and satisfaction on customer commitment to the relationship. According to Lee et al.'s (2007) study, trust in a retailer positively affects customer affective commitment towards the retailer. On the basis of the above discussion, the following hypotheses are proposed:

$\mathrm{H} 1$ : Trust in a retailer positively affects relationship satisfaction;

H2: Relationship satisfaction positively affects customer commitment to a retailer;

H3: Trust in a retailer positively affects customer commitment to a retailer.

\subsection{Customer orientation}

Front-line employees' attitude and behaviour towards customers in service encounters are widely acknowledged to have an impact on customer's perceptions of a service experience and service company. Customer orientation is an integral part of market orientation, in addition to competitor orientation and inter-functional coordination. Customer and market orientation have been shown to positively affect the company's performance (Andreou et al., 2020; Koshksaray et al., 2020) and overall satisfaction with the company's export performance (Njegic et al., 2020). Understanding and satisfying customers' needs in a manner superior to its competitors is at the forefront of customer orientation. According to Saxe and Weitz (1982), who were among the first authors to address the construct of customer orientation, customer-oriented behaviour is reflected in sales personnel's efforts to understand customers' needs and help customers achieve their goals, which provides a pathway to the establishment of mutually beneficial long-term relationships with customers. Customer-oriented behaviour of service personnel contributes to customer satisfaction, fosters trust and commitment to the relationship with service provider (Kim et al., 2006; Qin et al., 2009; Oraedu, 2019). Guenzi et al. (2009) asserted that retailing personnel who behave in a professional manner and who are friendly with customers and benevolent instill trust into customers. Friendly and helpful behaviour of grocery store employees has been shown to influence customer satisfaction and willingness to maintain relation- 
ship with a provider (Paul et al., 2016; Roozen \& Katidis, 2019). Based on these previous findings we propose the following hypotheses:

$\mathrm{H} 4 \mathrm{a}$ : Customer orientation is positively related to customer trust in a retailer;

H4b: Customer orientation is positively related to relationship satisfaction;

H4c: Customer orientation is positively related to customer commitment to a retailer.

\subsection{Attitudinal and behavioural loyalty}

Customer loyalty is regarded as the primary goal of relationship marketing and it has even been equated with relationship marketing (Hennig-Thurau et al., 2002). To remain loyal to a company customers should be satisfied with a company's offering and trust the supplier (Valenzuela et al., 2010). A number of studies differentiate between attitudinal and behavioural loyalty (e.g., Mandhachitara \& Poolthong, 2011; Lee et al., 2018; Ledikwe et al., 2019; Yao et al., 2019). According to Watson et al. (2015), attitudinal loyalty is based on a strong positive attitude, i.e. customer preference for a particular entity, which stems from positive evaluations of previous exchange experience. In highly competitive environments, strong positive attitudes activate defensive processes causing customers' resistance towards competitive offers. Behavioural loyalty implies repeat purchase behaviour which is based on a strong preference towards an entity. It differs from repeat purchases caused by the lack of alternatives, high switching costs or inertia (Dick \& Basu, 1994).

Previous research in the context of traditional and e-retailing has supported positive effects of relationship quality constructs on customers' attitudinal and behavioural loyalty (De Wulf et al., 2001; Guenzi et al., 2009; Park et al., 2017; Ledikwe et al., 2019). Based on these arguments, the present study puts forth the following hypotheses:

H5a: Trust in a retailer positively affects customer attitudinal loyalty;

$\mathrm{H} 5 \mathrm{~b}$ : Trust in a retailer positively affects customer behavioural loyalty;

H6a: Relationship satisfaction positively affects customer attitudinal loyalty;

H6b: Relationship satisfaction positively affects customer behavioural loyalty;

H7a: Commitment to a retailer positively affects customer attitudinal loyalty;

$\mathrm{H} 7 \mathrm{~b}$ : Commitment to a retailer positively affects customer behavioural loyalty.

Conceptual framework, which integrates hypothesized relationships, is displayed in Figure 1.

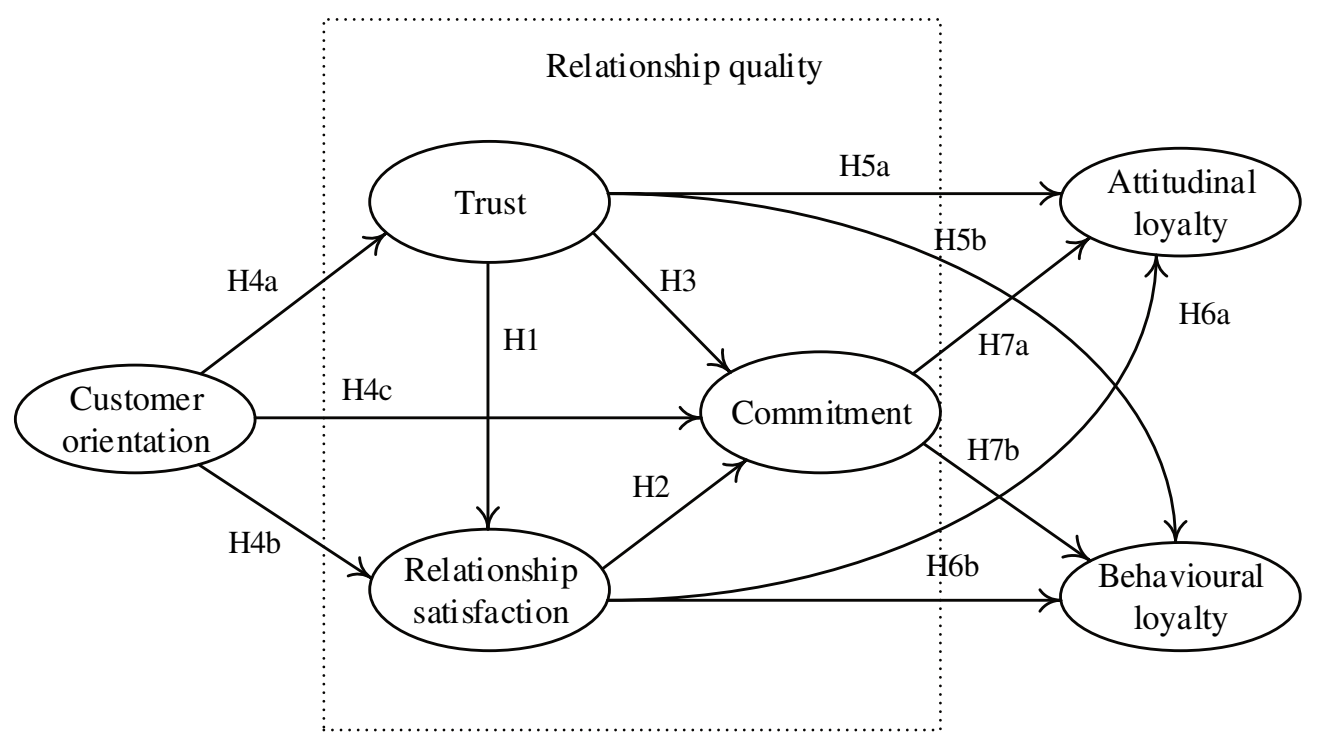

Figure 1. Conceptual framework 


\section{Methodology}

\subsection{Sample and data collection}

The study was conducted on a convenience sample of grocery retail customers in Serbia. Data collection was performed by means of self-administered structured questionnaire. Students attending Marketing course assisted in data collection. Respondents were addressed at their households. They were instructed by students to respond to questionnaire items taking into account their perceptions of a grocery retailer with whom they spend the most. Out of 512 delivered questionnaires, 453 completely fully completed questionnaires were included in the final analysis.

Female respondents who agreed to participate in the study outnumbered male respondents (57\% vs. $43 \%$ ). In terms of age groups, the highest percentage of respondents belong to age group 'up to 24 years of age' $(31 \%)$, followed by age groups ' $25-34$ years of age' $(22.9 \%)$ and ' $35-44$ years of age' $(20.5 \%)$. The frequency of other age groups is $15.1 \%$ ( $45-54$ years of age), $7.6 \%$ (55-64) and $2.9 \%$ (65 and older). A majority of respondents reported being educated up to the secondary level $(69.8 \%)$, followed by university education (14.2\%), college education (9\%) and elementary education (7\%).

\subsection{Measurement instrument}

The measurement instrument used in this study was based on previous research. Group discussions with retail customers preceded large-scale interviewing, on the grounds of which some modifications of the questionnaire were made, to enhance comprehensibility and readability of questionnaire items. Customer orientation was measured using six indicators, adapted from the works of Cheng et al. (2008) and Lo et al. (2017), reflecting retail employees' behaviour and attitude towards better understanding and meeting customers' needs. Trust was measured using four indicators adapted from Kim and Cha (2002). Three indicators adapted from the study of De Wulf et al. (2001) were used to measure relationship satisfaction. Commitment was measured with three items adapted from the studies of Lee et al. (2007) and OlavarrýaJaraba et al. (2018). Attitudinal and behavioural loyalty were measured using two items per construct, which were adapted from the works of Mandhachitara and Poolthong (2011) and Watson et al. (2015). All items were measured on a 7-point Likert-type scale ranging from 1-strongly disagree to 7-strongly agree.

\subsection{Data analysis}

Data analyses have been performed in compliance with Anderson and Gerbing's (1988) two-step approach, which implies the assessment of the psychometric properties of constructs by the application of confirmatory factor analysis (CFA), followed by the estimation of structural model and path coefficients. SPSS 17 and Amos 16 were used for data processing.

\section{Results}

\subsection{Measurement model analysis}

Confirmatory factor analysis was applied to examine the adequacy of the measurement model. The analysis resulted in a good fit of the model to the data. The overall fit indices were $X^{2} / \mathrm{df}=1.902, \mathrm{GFI}=0.941$, $\mathrm{AGFI}=0.919, \mathrm{CFI}=0.976, \mathrm{TLI}=0.971, \mathrm{NFI}=0.951, \mathrm{RMSEA}=0.045$. As the strength of relationships among latent variables can only be meaningfully interpreted if construct validity, comprising convergent and discriminant validity, is established, the study first focused on the examination of these types of validity. Evidence in support of convergent validity of the study's constructs was provided by the acceptable level of composite reliabilities of the constructs $(\rho \geq 0.60$; Bagozzi \& Yi, 1988) and average variances extracted higher than 0.50 (Fornell \& Larcker, 1981), with the exception of variance extracted of customer orientation, which was slightly lower than 0.50 , and statistically significant standardized factor loadings above 0.50 (Anderson \& Gerbing, 1988), as presented in Table 1. 
Table 1: Measurement model results

\begin{tabular}{|c|c|c|c|c|c|}
\hline Constructs and items & $\begin{array}{c}\text { St. } \\
\text { factor } \\
\text { loadings }\end{array}$ & t-value & $\begin{array}{l}\text { Average } \\
\text { variance } \\
\text { extracted } \\
\text { (AVE) }\end{array}$ & $\begin{array}{l}\text { Composite } \\
\text { reliability }\end{array}$ & $\begin{array}{l}\text { Cronbach's } \\
\text { alpha* }\end{array}$ \\
\hline Customer orientation & & & 0.45 & 0.830 & 0.827 \\
\hline $\begin{array}{l}\text { Retail employees are friendly with } \\
\text { customers }\end{array}$ & 0.719 & - & & & \\
\hline $\begin{array}{l}\text { Retail employees are willing to offer } \\
\text { help to customers }\end{array}$ & 0.648 & 12.515 & & & \\
\hline $\begin{array}{l}\text { Retail employees are courteous } \\
\text { with customers in handling } \\
\text { customers' inquiries/complaints }\end{array}$ & 0.607 & 11.755 & & & \\
\hline $\begin{array}{l}\text { Retail employees are } \\
\text { knowledgeable about customers' } \\
\text { needs }\end{array}$ & 0.674 & 12.987 & & & \\
\hline $\begin{array}{l}\text { Retail employees try to anticipate } \\
\text { customers' needs }\end{array}$ & 0.716 & 13.725 & & & \\
\hline $\begin{array}{l}\text { Retail employees have customers' } \\
\text { best interest in mind }\end{array}$ & 0.655 & 12.645 & & & \\
\hline Trust & & & 0.64 & 0.878 & 0.887 \\
\hline The retailer keeps promises & 0.873 & - & & & \\
\hline The retailer is honest & 0.814 & 20.627 & & & \\
\hline The retailer is reliable & 0.714 & 16.843 & & & \\
\hline $\begin{array}{l}\text { The retailer puts customers' } \\
\text { interests first }\end{array}$ & 0.802 & 20.090 & & & \\
\hline Relationship satisfaction & & & 0.71 & 0.879 & 0.875 \\
\hline $\begin{array}{l}\text { I have a high-quality relationship } \\
\text { with this retailer }\end{array}$ & 0.808 & - & & & \\
\hline $\begin{array}{l}\text { I am happy with the efforts this } \\
\text { retailer is making towards regular } \\
\text { customers like me }\end{array}$ & 0.871 & 21.507 & & & \\
\hline $\begin{array}{l}\text { I am satisfied with the relationship I } \\
\text { have with this retailer }\end{array}$ & 0.846 & 20.661 & & & \\
\hline Commitment & & & 0.66 & 0.850 & 0.852 \\
\hline $\begin{array}{l}\text { I feel emotionally attached to this } \\
\text { retailer }\end{array}$ & 0.783 & - & & & \\
\hline $\begin{array}{l}\text { This retailer has a great deal of } \\
\text { personal meaning for me }\end{array}$ & 0.856 & 18.743 & & & \\
\hline $\begin{array}{l}\text { I feel a sense of belonging to this } \\
\text { retailer }\end{array}$ & 0.787 & 17.199 & & & \\
\hline Attitudinal loyalty & & & 0.82 & 0.902 & 0.822 \\
\hline $\begin{array}{l}\text { I would say positive things about } \\
\text { this retailer }\end{array}$ & 0.899 & - & & & \\
\hline I prefer this retailer over competitors & 0.914 & 29.153 & & & \\
\hline Behavioural loyalty & & & 0.73 & 0.842 & 0.727 \\
\hline $\begin{array}{l}\text { I buy more often from this retailer in } \\
\text { comparison with other retailers }\end{array}$ & 0.871 & - & & & \\
\hline $\begin{array}{l}\text { I intend to make most of my future } \\
\text { purchases with this retailer }\end{array}$ & 0.835 & 21.331 & & & \\
\hline
\end{tabular}

*Note: Cronbach Alpha coefficients are calculated for factors containing at least three items, Spearman-Brown coefficients are presented for two-item constructs

Reliability of the constructs was assessed by calculating Cronbach's alpha coefficients, i.e. Spearman-Brown coefficients in case of two-item constructs (Eisinga et al., 2013). As all coefficients were higher than the lower threshold of 0.70 , evidence was provided in support of constructs' reliability (Hair et al., 2010). Evidence in support of discriminant validity was provided as none of the $95 \%$ confidence intervals $(\mathrm{Cl})$ of constructs' correlations included unity (Anderson \& Gerbing, 1988), as presented in Table 2. Bootstrapping procedure with 500 bootstrap samples was applied to obtain confidence intervals. 
Table 2: Correlations among the constructs and $95 \%$ confidence intervals of correlations

\begin{tabular}{|c|c|c|c|c|c|c|}
\hline & $\begin{array}{l}\text { Customer } \\
\text { orientation }\end{array}$ & Trust & $\begin{array}{l}\text { Relationship } \\
\text { satisfaction }\end{array}$ & Commitment & $\begin{array}{l}\text { Attitudinal } \\
\text { loyalty }\end{array}$ & $\begin{array}{c}\text { Behavioural } \\
\text { loyalty }\end{array}$ \\
\hline $\begin{array}{l}\text { Customer } \\
\text { orientation }\end{array}$ & 1 & & & & & \\
\hline Trust & $\begin{array}{l}0.584 \\
(0.494 \\
0.685)\end{array}$ & 1 & & & & \\
\hline $\begin{array}{l}\text { Relationship } \\
\text { satisfaction }\end{array}$ & $\begin{array}{l}0.644 \\
(0.560 \\
0.726)\end{array}$ & $\begin{array}{l}0.718 \\
(0.624 \\
- \\
0.783) \\
\end{array}$ & 1 & & & \\
\hline Commitment & $\begin{array}{l}0.558 \\
(0.461 \\
0.642)\end{array}$ & $\begin{array}{l}0.651 \\
(0.558 \\
- \\
0.710) \\
\end{array}$ & $\begin{array}{l}0.717 \\
(0.626 \\
0.781)\end{array}$ & 1 & & \\
\hline $\begin{array}{l}\text { Attitudinal } \\
\text { loyalty }\end{array}$ & $\begin{array}{l}0.612 \\
(0.520 \\
0.708)\end{array}$ & $\begin{array}{l}0.721 \\
(0.637 \\
- \\
0.789) \\
\end{array}$ & $\begin{array}{l}0.900 \\
(0.847 \\
0.931)\end{array}$ & $\begin{array}{l}0.759 \\
(0.690 \\
0.805)\end{array}$ & 1 & \\
\hline $\begin{array}{l}\text { Behavioural } \\
\text { loyalty }\end{array}$ & $\begin{array}{l}0.581 \\
(0.471 \\
0.652)\end{array}$ & $\begin{array}{l}0.618 \\
(0.515 \\
- \\
0.694) \\
\end{array}$ & $\begin{array}{l}0.829 \\
(0.748 \\
0.895)\end{array}$ & $\begin{array}{l}0.792 \\
(0.712 \\
0.865)\end{array}$ & $\begin{array}{l}0.858 \\
(0.781 \\
0.917)\end{array}$ & 1 \\
\hline
\end{tabular}

Note: correlations are significant at the 0.05 level; $95 \%$ confidence intervals of correlations are given in brackets

Acceptable measurement model analysis allowed for the examination of proposed structural relationships. Prior to the examination of the structural model, the presence of common method bias was examined, by the application of the CFA technique.

The common method variance can mask true relationships between variables and pose a problem in marketing research (MacKenzie \& Podsakoff, 2012; Podsakoff et al., 2012). It may happen when responses are collected on the same scale format, from the same source, at the same point in time and by means of a single questionnaire, as was the case with this study. In line with statistical remedies suggested by Podsakoff et al. (2012), the CFA analysis was applied to examine the presence of the common method variance. Lack of fit of a single-factor model indicated that the common method bias was not a serious problem of this study $(\mathrm{X} 2 / \mathrm{df}=8.850, \mathrm{GFI}=0.701, \mathrm{AGFI}=0.630, \mathrm{CFI}=0.771, \mathrm{TLI}=0.745, \mathrm{NFI}=0.750, \mathrm{RMSEA}=0.132)$.

\subsection{Structural model analysis}

Structural equation modelling yielded acceptable model fit, as indicated by the following indices: $\mathrm{X}^{2} / \mathrm{df}=$ 1.947, GFI=0.939, AGFI=0.918, CFI=0.975, TLI=0.969, NFI=0.949, RMSEA $=0.046$.

The results of SEM, which are presented in Table 3, provide support for 9 out of 12 hypotheses. Direct, indirect and total contribution of the constructs to attitudinal and behavioural loyalty is displayed in Table 4.

Table 3: Structural model results

\begin{tabular}{|l|c|c|c|}
\hline Relationships & $\begin{array}{c}\text { Standardized } \\
\text { estimates }\end{array}$ & t-value & $\begin{array}{c}\text { Hypothesis } \\
\text { testing }\end{array}$ \\
\hline H1: Trust $\rightarrow$ Relationship satisfaction & 0.525 & 9.513 & Supported \\
\hline H2: Relationship satisfaction $\rightarrow$ commitment & 0.467 & 6.040 & Supported \\
\hline H3: Trust $\rightarrow$ Commitment & 0.250 & 3.654 & Supported \\
\hline H4a: Customer orientation $\rightarrow$ trust & 0.583 & 10.276 & Supported \\
\hline H4b: Customer orientation $\rightarrow$ relationship satisfaction & 0.341 & 6.239 & Supported \\
\hline H4c: Customer orientation $\rightarrow$ commitment & 0.111 & 1.812 & Not supported \\
\hline H5a: Trust $\rightarrow$ Attitudinal loyalty & 0.061 & 1.270 & Not supported \\
\hline H5b: Trust $\rightarrow$ Behavioural loyalty & -0.110 & -1.888 & Not supported \\
\hline H6a: Relationship satisfaction $\rightarrow$ Attitudinal loyalty & 0.722 & 11.726 & Supported \\
\hline H6b: Relationship satisfaction $\rightarrow$ Behavioural loyalty & 0.632 & 8.995 & Supported \\
\hline H7a: Commitment $\rightarrow$ Attitudinal loyalty & 0.208 & 4.156 & Supported \\
\hline H7b: Commitment $\rightarrow$ Behavioural loyalty & 0.416 & 6.674 & Supported \\
\hline
\end{tabular}


Although trust did not emerge as a significant direct determinant of attitudinal, nor behavioural loyalty, findings of the study indicate statistically significant indirect contribution of trust to loyalty constructs, mediated via satisfaction and commitment, as presented in Table 4. Both commitment and relationship satisfaction emerged as direct antecedents of customers' loyalty intentions. In terms of total effect, relationship satisfaction emerged as the most significant driver of both attitudinal and behavioural loyalty. This finding highlights the importance of establishing satisfying relationships with customers to reap the benefits of being recommended to other prospective customers and ensure future sales. According to this study's findings, customer orientation directly contributes to trust in a retailer and relationship satisfaction and indirectly determines commitment towards the retailer and customers' attitudinal and behavioural loyalty.

Table 4: Direct, indirect and total effects

\begin{tabular}{|c|c|c|c|c|c|c|c|c|c|c|c|}
\hline & \multicolumn{4}{|c|}{ Direct effect } & \multicolumn{3}{c|}{ Indirect effect } & \multicolumn{3}{c|}{ Total effect } \\
\hline & CO & TR & SAT & CM & CO & TR & SAT & CO & TR & SAT & CM \\
\hline TR & $0.583^{\star}$ & & & & & & & $0.583^{\star}$ & & & \\
\hline SAT & $0.341^{\star \star}$ & $0.525^{\star}$ & & & $0.306^{\star}$ & & & $0.647^{\star \star}$ & $0.525^{\star}$ & & \\
\hline CM & n.s. & $0.250^{\star}$ & $0.467^{\star \star}$ & & $0.448^{\star \star}$ & $0.245^{\star \star}$ & & $0.559^{\star}$ & $0.495^{\star \star}$ & $0.467^{\star \star}$ & \\
\hline BL & & n.s. & $0.632^{\star \star}$ & $0.416^{\star}$ & $0.577^{\star}$ & $0.538^{\star}$ & $0.194^{\star \star}$ & $0.577^{\star}$ & $0.428^{\star}$ & $0.826^{\star \star}$ & $0.416^{\star}$ \\
\hline AL & & n.s. & $0.722^{\star \star}$ & $0.208^{\star}$ & $0.619^{\star}$ & $0.482^{\star}$ & $0.097^{\star \star}$ & $0.619^{\star}$ & $0.543^{\star}$ & $0.819^{\star \star}$ & $0.208^{\star}$ \\
\hline
\end{tabular}

Note: *parameter estimate is significant at the 0.05 level; **significance at the 0.01 level; CO-Customer orientation, TR-trust, SAT-Relationship satisfaction, CM-commitment, AL-attitudinal loyalty, BL-behavioural loyalty

\section{Discussion}

This study aimed to propose and empirically examine a relationship quality model in heretofore under-studied context of $\mathrm{B} 2 \mathrm{C}$ exchange relations in an Eastern European emerging economy. In line with previous research (Balaji, 2015; Izogo, 2016), relationship quality has been modelled as a disaggregated construct, comprising trust in a retailer, relationship satisfaction and commitment towards a retailer. Taking into account total effects of relationship quality constructs on attitudinal and behavioural loyalty of customers, the findings of this study concur with prior research indicating significant effect of relationship quality on customer loyalty (Taylor et al., 2018; Ledikwe et al., 2019; Prayag et al., 2019). Not surprisingly, relationship satisfaction emerged as the strongest direct determinant of both attitudinal and behavioural loyalty and the most significant precursor to loyalty intentions, in terms of total effect. This finding indicates that customers' loyalty intentions are to the greatest extent influenced by customers' impressions of having a good relationship with a retailer and customers' recognition of the retailer's efforts towards regular customers.

Consistent with the findings of previous research in B2C settings (Izogo, 2016; Lo et al., 2017; OlavarrýaJaraba et al., 2018; Prayag et al., 2019), the present study indicates that the enhancement of retailers' customer orientation, i.e. employees' courteousness and willingness to help customers, positively affects customer trust in a retailer and relationship satisfaction. In spite of a non-significant direct effect of trust in a retailer on attitudinal and behavioural loyalty, findings of this study indicate a contributional mechanism of trust in the enhancement of customers' willingness to spread positive word-of-mouth and continue purchasing from the same company. As such, this finding is consistent with Balaji's (2015) results indicating satisfaction and commitment as mediators of trust - customer loyalty relationship. One should also note that commitment towards a retailer, in spite of its significant direct effect on attitudinal and behavioural loyalty, does not play a decisive role in ensuring customer loyalty intentions in the context of grocery retailing. In terms of total effect, customer orientation emerged as a more influential determinant of loyalty, in comparison with commitment. This finding may indicate that in the context of services rich in search and experience qualities, such as grocery retailing, commitment towards the provider is less significant than customers' perceptions of service personnel' positive attitude and behaviour for the formation of loyalty intentions. The adopton of customer orientation by front-line retailing employees, as indicated by this study's findings, is relevant for the establishment and maintenance of quality relationship with customers, which is expected to bring in new customers, by referrals of the existing ones, and contribute to retailer's future earnings, by customers' repurchase behaviour. 
Conclusion

\section{Theoretical and managerial implications}

By examining the antecedent role of employees' customer orientation and the contributional mechanism of relationship quality constructs to the formation of customers' loyalty intentions, in the context of a service industry exposed to rising competitive pressures operating in an emerging economy, this study contributes to Relationship Marketing literature. To the best of our knowledge, this is the first study to illuminate the contributional mechanism of relationship quality constructs to the development of customer loyalty in a B2C context in an emerging European economy.

This research findings have the potential to assist retail managers in the development of effective relationship marketing strategies. Taking into consideration the strongest direct impact of satisfaction on attitudinal and behavioural loyalty, the findings of this study indicate that retailers should invest into the establishment of satisfying relationships with customers and therewith provide the foundation for the establishment of long-term cooperation with customers. A significant positive impact of customer orientation on trust and relationship satisfaction also bears important managerial information for retailers. On the grounds of these findings, human resource managers should ensure that the relevance of respectful attitude towards customers, understanding, anticipating and satisfying customers' needs are instilled into retail employees and reinforced by training, supervision and rewarding activities of HR departments.

\section{Limitations and directions for future research}

Some limitations of the study should be noted. Researchers are advised not to generalize this study's findings to the context of grocery retailing in emerging economies in general, as the study has been performed on a convenience sample of grocery retail customers of one emerging economy. This study's findings are based on cross-sectional data, which only allows for correlational inferences to be made. Therefore, future research should be conducted using a longitudinal study design. In addition, as this study was conducted in a single-country setting, cross-national research is welcome to uncover whether cultural differences have an impact on the development and effects of relationship quality in a retail industry in emerging economies. One limitation of this research is also reflected in average variance extracted of customer orientation construct, which emerged slightly lower than the lower threshold of 0.50 . This drawback of the study possibly indicates that there are some additional facets of customer orientation which are relevant from the perspective of grocery retail customers, but which have been overseen in the course of this study. Therefore, future researchers are advised to probe more deeply into the construct of customer orientation, especially taking into consideration the relevance of its total effect on the formation of customers' loyalty intentions.

One should also be aware that not all customers are equally willing to establish relationships with service providers (Noble \& Phillips, 2004; Rajaobelina \& Bergeron, 2009). As evidenced by Delacroix and Guillard (2016), some consumers feel social anxiety in commercial exchange settings, i.e. reluctance to establish relationships with sales personnel. As customers differ in terms of relational preferences, future research would benefit from examining the moderating role of relational preference on the impact of customer orientation on relationship quality constructs. It would be especially interesting to study the aforementioned moderating influence in service settings which require longer interactions or interactions which are repeated over time or non-standardized interactions, and particularly in emerging economies where customers are less accustomed to self-disclosure in commercial exchange relationships. Another drawback of this study is the proposal of employees' customer orientation as the sole antecedent to relationship quality. Recent research in service settings has suggested significant impact of service quality, price fairness and relationship benefits on relationship quality (Oraedu, 2019; Prayag et al., 2019). Therefore, proposal and examination of a more comprehensive framework of relationship quality would be an avenue worthy of future examination.

\section{REFERENCES}

[1] Anderson, J. C., \& Gerbing, D. W. (1988). Structural equation modeling in practice: A review and recommended two-step approach. Psychological Bulletin, 103, 411-423. DOI:10.1037/0033-2909.103.3.411

[2] Andreou, P. C., Harris, T., \& Philip, D. (2020). Measuring Firms' Market Orientation Using Textual Analysis of 10-K Filings. British Journal of Management, DOI:10.1111/1467-8551.12391

[3] Athanasopoulou, P. (2009). Relationship quality: a critical literature review and research agenda. European Journal of Marketing, 43(5/6), 583-610. DOI:10.1108/03090560910946945

[4] Bagozzi, R. P., \& Yi, Y. (1988). On the evaluation of structural equation models. Journal of the Academy of Marketing Science, 16, 74-94. DOI:10.1177/009207038801600107

[5] Bakator, M., Djordjevic, D., Cockalo, D., \& Bogetic, S. (2019). The Impact of Consumer-Company Relationships on Brand Loyalty. Management: Journal Of Sustainable Business And Management Solutions In Emerging Economies, . DOI:10.7595/management.fon.2019.0016 
[6] Balaji, M.S. (2015). Investing in customer loyalty: the moderating role of relational characteristics. Service Business, 9(1), 17-40. DOI:10.1007/s11628-013-0213-y

[7] Bowden-Everson, J. L.-H. , Dagger, T. S., \& Elliott, G. (2013). Engaging Customers for Loyalty in the Restaurant Industry: The Role of Satisfaction, Trust, and Delight. Journal of Foodservice Business Research, 16(1), 52-75. DOI: 10.1080/15378020.2013.761025

[8] Castellanos-Verdugo, M., Oviedo-Garcia, M.A., Roldan, J.L. \& Veerapermal, N. (2009). The employeecustomer relationship quality: antecedents and consequences in the hotel industry. International Journal of Contemporary Hospitality Management, $21(3), 251-274$. DOI: 10.1108/09596110910948288

[9] Cheng, J.-H., Chen, F.-Y., \& Chang, Y.-H. (2008). Airline relationship quality: An examination of Taiwanese passengers. Tourism Management, 29, 487-499. DOI:10.1016/j.tourman.2007.05.015

[10] Commission for protection of competition of the Republic of Serbia, Sectoral analysis, Report on the retail sector inquiry into the sale in non-specialized stores with food, beverages and tobacco predominating, January 29, 2019, Retrieved from: http://www.kzk.gov.rs/en/category/sektorske-analize

[11] De Wulf, K., Odekerken-Schröder, G., \& lacobucci, D. (2001). Investments in Consumer Relationships: A Cross-Country and Cross-Industry Exploration. Journal of Marketing, 65, 33-50. DOI:10.1509/jmkg.65.4.33.18386

[12] Delacroix, E., \& Guillard, V. (2016). Consumers who avoid relationships: social anxiety in commercial contexts. Journal of Consumer Behaviour, 15, 370-384. DOI:10.1002/cb.1582

[13] Dick, A. \& Basu, K. (1994). Customer loyalty: toward an integrated conceptual framework. Journal of the Academy of Marketing Science, 22(2), 99-113.

[14] Eisinga, R., Grotenhuis, M., \& Pelzer, B. (2013). The reliability of a two-item scale: Pearson, Cronbach or Spearman-Brown?. International Journal of Public Health, 58(4), 637-642. DOI: 10.1007/s00038-0120416-3

[15] Fornell, C., \& Larcker, D. F. (1981). Evaluating structural equation models with unobservable variables and measurement error. Journal of Marketing Research, 18(1), 39-50. DOI: 10.2307/3151312

[16] Fullerton, G. (2005). The service quality-loyalty relationship in retail services: does commitment matter?. Journal of Retailing and Consumer Services, 12, 99-111. DOI:10.1016/j.jretconser.2004.04.001

[17] Guenzi, Pa., Johnson, M. D., \& Castaldo, S. (2009). A comprehensive model of customer trust in two retail stores. Journal of Service Management, 20(3), 290-316. DOI:10.1108/09564230910964408

[18] Hair, J. F. Jr., Black, W. C., Babin, B. J., \& Anderson R. E. (2010). Multivariate Data Analysis: A Global Perspective (7th ed.). New Jersey: Pearson Education Inc.

[19] Hennig-Thurau, T., Gwinner, P. K., \& Gremler, D. D. (2002). Understanding relationship marketing outcomes: An integration of relational benefits and relationship quality. Journal of Service Research, 4(3), 230-247. DOI:10.1177/1094670502004003006

[20] Izogo, E. E. (2016). Should relationship quality be measured as a disaggregated or a composite construct?. Management Research Review, 39(1), 115-131. DOI:10.1108/MRR-10-2014-0232

[21] Kim, W. G., \& Cha, Y. (2002). Antecedents and consequences of relationship quality in hotel industry. International Journal of Hospitality Management, 21, 321-338. DOI:10.1016/S0278-4319(02)00011-7

[22] Kim, W. G., Lee, Y.-K., \& Yoo, Y.J. (2006). Predictors of Relationship Quality and Relationship Outcomes in Luxury Restaurants. Journal of Hospitality \& Tourism Research, 30, 143-169. DOI:10.1177/1096348005285086

[23] Koshksaray, A. A., Ardakani, A. A., Ghasemnejad, N., \& Azbari, A. Q. (2020). The effect of customer orientation coaching on employee's individual performance and financial and non-financial performance: A case of Tejarat bank in Iran. International Journal of Islamic and Middle Eastern Finance and Management, 13(3), 437-469. DOI10.1108/IMEFM-04-2019-0169

[24] Kuhn, S. \& Mostert, P. (2018) Relationship intention and relationship quality as predictors of clothing retail customers' loyalty. The International Review of Retail, Distribution and Consumer Research, 28(2), 206-230. DOI: 10.1080/09593969.2017.1380067

[25] Ledikwe, A., Roberts-Lombard, M., \& Klopper, H. B. (2019). The perceived influence of relationship quality on brand loyalty. African Journal of Economic and Management Studies., 10(1), 85-101. DOI:10.1108/AJEMS-04-2018-0113

[26] Lee, K.-Y., Huang, H.-L., \& Hsu, Y.-C. (2007). Trust, Satisfaction and Commitment - On Loyalty to International Retail Service Brands, Asia Pacific Management Review, 12(3), 161-169.

[27] Lee, C. K. M., Ng, K. K. H., Chan, H. K., Choy, K. L., Tai, W. C., \& Choi, L. S. (2018). A multi-group analysis of social media engagement and loyalty constructs between full-service and low-cost carriers in Hong Kong. Journal of Air Transport Management, 73, 46-57. DOI: 10.1016/j.jairtraman.2018.08.009

[28] Lo, A. S., Hyunjung, I. H., Chen, Y., \& Qu, H. (2017). Building brand relationship quality among hotel loyalty program members. International Journal of Contemporary Hospitality Management, 29(1), 458-488. DOI:10.1108/IJCHM-06-2015-0283

[29] MacKenzie, S. B., \& Podsakoff, P. M. (2012). Common Method Bias in Marketing: Causes, Mechanisms, and Procedural Remedies. Journal of Retailing, 88(4), 542-555. DOI:10.1016/j.jretai.2012.08.001 
[30] Mandhachitara, R., \& Poolthong, Y. (2011). A model of customer loyalty and corporate social responsibility. Journal of Services Marketing, 25(2), 122-133. DOI 10.1108/08876041111119840

[31] Moorman, C., Zaltman, G., \& Deshpande, R. (1992). Relationships between providers and users of market research: The dynamics of trust within and between organizations. Journal of Marketing Research, 29(3), 314-328. DOI: 10.2307/3172742

[32] Njegic, K., Djokic, I., \& Milanovic, V. (2020). Testing MKTOR Scale Properties in Serbian Exporters' Context. Management: Journal Of Sustainable Business And Management Solutions In Emerging Economies, 25(1), 37-46. DOI:10.7595/management.fon.2019.0011

[33] Noble, S. M. \& Phillips, J. (2004). Relationship hindrance: why would consumers not want a relationship with a retailer?. Journal of Retailing, 80, 289-303. DOI:10.1016/j.jretai.2004.10.005

[34] Olavarrýa-Jaraba, A., Cambra-Fierro, J. J., Centeno, E., \& Vazquez-Carrasco, R. (2018). Analyzing relationship quality and its contribution to consumer relationship proneness. Service Business, 12, 641661. DOI:10.1007/s11628-018-0362-0

[35] Oraedu, C. (2019). Structural Equation Test of Service Quality Dimensions on the Relationship Quality Construct: Evidence from an Emerging Telecom Market. Journal of Relationship Marketing, 18(2), 146171. DOI: $10.1080 / 15332667.2018 .1534066$

[36] Palmatier, R.W., Dant, R.P., Grewal, D. \& Evans, K.R. (2006). Factors influencing the effectiveness of relationship marketing: a meta-analysis. Journal of Marketing, 70(4), 136-153. DOI:10.1509/jmkg.70.4.136

[37] Park, E., Kim, K. J., \& Kwon, S. J. (2017). Corporate social responsibility as a determinant of consumer loyalty: An examination of ethical standard, satisfaction, and trust. Journal of Business Research, 76, 813. DOI:10.1016/j.jbusres.2017.02.017

[38] Paul J., Sankaranarayanan, K. G. \& Mekoth, N (2016). Consumer satisfaction in retail stores: theory and implications. International Journal of Consumer Studies, 40, 635-642. DOI:10.1111/ijcs.12279

[39] Podsakoff, P. M., MacKenzie, S. B., \& Podsakoff, N. P. (2012). Sources of Method Bias in Social Science Research and Recommendations on How to Control It. Annual Review of Psychology, 63, 539-569. DOI:10.1146/annurev-psych-120710-100452

[40] Prayag, G., Hosany, S., Taheri, B., \& Ekiz, E. H. (2019). Antecedents and outcomes of relationship quality in casual dining restaurants: The mediating effects of relationship quality and moderating roles of gender. International Journal of Contemporary Hospitality Management, 31(2), 575-593. DOI:10.1108/IJCHM-10-2017-0706

[41] Qin, S., Zhao, L., \& Yi, X. (2009). Impacts of customer service on relationship quality: an empirical study in China. Managing Service Quality, 19(4), 391-409. DOI:10.1108/09604520910971520

[42] Rajaobelina, L., \& Bergeron, J. (2009). Antecedents and consequences of buyer-seller relationship quality in the financial services industry. International Journal of Bank Marketing, 27(5), 359-380. DOI:10.1108/02652320910979889

[43] Rajic, T., Nikolic, I., \& Milosevic, I. (2019). An Integrative Model of Relationship Quality in Higher Education Setting: Evidence from Serbia, Industry, 47(2), 43-59. DOI:10.5937/industrija47-22044

[44] Roozen, I., \& Katidis, P. I. (2019). The Importance of the Service and Shopping Customer Experience in a Retail Environment. Journal of Relationship Marketing, 18(4), 247-279. DOI:10.1080/15332667.2019.1619064.

[45] Santouridis, I., \& Veraki, A. (2017). Customer relationship management and customer satisfaction: the mediating role of relationship quality. Total Quality Management \& Business Excellence, 28(10), 1122 1133. DOI: $10.1080 / 14783363.2017 .1303889$

[46] Saxe, R., \& Weitz, B. A. (1982). The SOCO Scale: A Measure of the Customer Orientation of Salespeople. Journal of Marketing Research, 19(3), 343-351. DOI: 10.2307/3151568

[47] Taylor, S. Jr., DiPietro, R. B., \& Fung, S. K. K. (2018). Increasing experiential value and relationship quality: An investigation of pop-up dining experiences. International Journal of Hospitality Management, 74, 45-56. DOI:10.1016/j.ijhm.2018.02.013

[48] Valenzuela, L. M., Mulki, J. P., \& Jaramillo, J. F. (2010). Impact of Customer Orientation, Inducements and Ethics on Loyalty to the Firm: Customers' Perspective. Journal of Business Ethics, 93, 277-291. DOI 10.1007/s10551-009-0220-z

[49] Watson, G. F., Beck, J. T., Henderson, C. M., \& Palmatier, R. W. (2015). Building, measuring, and profiting from customer loyalty. Journal of the Academy of Marketing Science, 43(6), 790-825. DOI 10.1007/s11747-015-0439-4

[50] Wu, H.-C., Cheng, C.-C., \& Hussein, A. S. (2019). What drives experiential loyalty towards the banks? The case of Islamic banks in Indonesia. International Journal of Bank Marketing., 37(2), 595-620. DOI:10.1108/ijbm-04-2018-0101

[51] Xu, M., Lai, I. K. W., \& Tang, H. (2020). From corporate environmental responsibility to purchase intention of Chinese buyers: The mediation role of relationship quality. Journal of Consumer Behaviour, DOI:10.1002/cb.1857 
[52] Yao, T., Qiu, Q., \& Wei, Y. (2019). Retaining hotel employees as internal customers: Effect of organizational commitment on attitudinal and behavioral loyalty of employees. International Journal of Hospitality Management, 76, 1-8. DOI:10.1016/j.ijhm.2018.03.018

\section{Acknowledgements}

The authors gratefully acknowledge the scholarship for research stay in Slovakia granted by the Slovak Academic Information Agency, which facilitated collaboration on this study.

Received: 2020-08-27

Revisions requested: 2020-11-11

Revised: 2021-02-20 (2 revisions)

Accepted: 2021-03-16
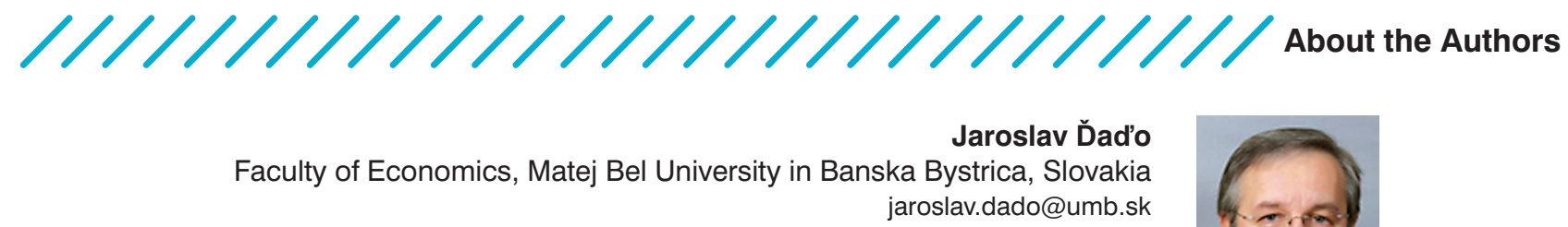

Jaroslav Ďad'o is a Full Professor at the Faculty of Economics, Matej Bel University in Banska Bystrica, Slovakia. His main specialization is Marketing and related disciplines, such as Strategic Marketing, International Marketing, Marketing Communication, Brand

Management. He participated in the MBA program organized with Nottingham Trent

University and as a lecturer he cooperated with a number of foreign universities (in

England, Poland, Turkey, Lithuania, Czech Republic, Hungary, Ukraine). He has

participated in a number of Slovak and international research teams and published a number of research papers and books related to Marketing Analysis, International Marketing, Services Marketing, Marketing Strategies.

\section{Janka Táborecká-Petrovičová Faculty of Economics, Matej Bel University in Banska Bystrica, Slovakia janka.taborecka@umb.sk}

Janka Táborecká - Petrovičová is an Associate Professor, Deputy Head of the Department of Corporate Economics and Management and a member of Scientific Committee at the Faculty of Economics, Matej Bel University, Banská Bystrica, Slovakia. Previously she worked as a module leader and consultant within the MBA study in cooperation with Nottingham Trent University. Her research interests cover areas of consumer behaviour, strategic marketing and biometric technologies. She published various papers in scientific journals in these fields and participated in many domestic and international projects and conferences. Currently she is also an editorial board member and reviewer in various international journals.
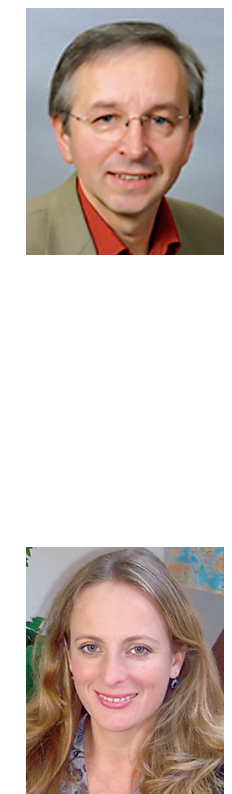

\section{Tamara Rajić Economics Institute a.d. Belgrade, Serbia tamara.rajic@ecinst.org.rs}

Tamara Rajić is a research associate at Economics Institute a.d., Belgrade. Her research focus is consumer behaviour across service industries. She received her Ph.D. from the

Faculty of Organisational Sciences, University of Belgrade. Results of the studies in which she participated have been published in Total Quality Management \& Business Excellence, Journal of Economics, E\&M Economics and Management and presented at

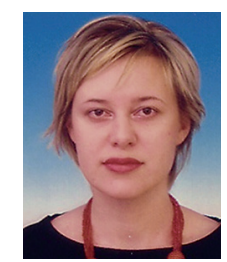
a number of national and international conferences. 